\title{
Mikroakışkan Platformda Proteine Bağlı Üremik Toksin Adsorpsiyonunun Modellenmesi
}

\author{
Esra İlhan-Ayışı $\breve{g}_{1}^{1,2}$, Şeyma Tırak ${ }^{3}$, Aylin Özünlü ${ }^{4}$ Ece Yıldız-Öztürk ${ }^{5}$, Özlem Yeşil-Çeliktaş5,6* \\ ${ }^{1}$ Ege Üniversitesi, Mühendislik Fakültesi, Biyomühendislik Bölümü, İzmir, Türkiye, (ORCID: 0000-0003-1880-4261), esrailhan01@gmail.com \\ ${ }^{2}$ Ahi Evran Üniversitesi, Mühendislik-Mimarlık Fakültesi, Genetik ve Biyomühendislik Bölümü, Kırşehir, Türkiye \\ ${ }^{3}$ Ege Üniversitesi, Mühendislik Fakültesi, Biyomühendislik Bölümü, İzmir, Türkiye (ORCID: 0000-0002-1638-514X), tirakseyma@gmail.com \\ ${ }^{4}$ Ege Üniversitesi, Mühendislik Fakültesi, Biyomühendislik Bölümü, İzmir, Türkiye (ORCID: 0000-0002-7094-3261), aylinozunlu@gmail.com \\ 5 Ege Üniversitesi, Solunum Araştırmaları Merkezi (ORCID: 0000-0003-2482-7371), eceyildiz.bioeng@gmail.com

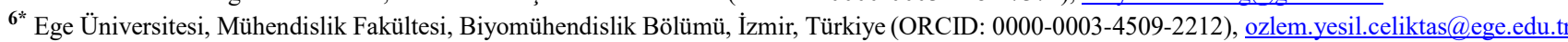

(İlk Geliş Tarihi 14 Temmuz 2021 ve Kabul Tarihi 9 Eylül 2021)

(DOI: 10.31590/ejosat.971386)

ATIF/REFERENCE: İlhan-Ayışı̆̆ı, E., Tırak, Ş., Özünlü, A., Yııldı-Öztürk, E. \& Yeşil-Çeliktaş, Ö. (2021). Mikroakışkan Platformda Proteine Bağlı Üremik Toksin Adsorpsiyonunun Modellenmesi. Avrupa Bilim ve Teknoloji Dergisi, (27), 354-361.

$\ddot{O} z$

$\mathrm{Bu}$ çalışmada kronik böbrek hastalarının üremik toksisite sorununa çözüm bulmak amacıyla hemodiyaliz sistemine entegre edilebilecek bir mikroakışkan çipin geliştirilmesi hedeflenmiştir. Mikroakışkan çip içerisine Sol-Jel metodu ile Na-Y Zeolit ile fonksiyonelleştirilmiş TEOS-PEO hidrojeli yüklenerek, kanda bulunan ve proteine bağlı üremik toksinlerden biri olan İndoksil Sülfat (IS) toksininin, çip içerisinde adsorbe edilerek hastaların kanlarından uzaklaştırılması hipotezi test edilmiştir. Solid Works programı ile S-şekilli bir mikrokanal tasarlanarak, Comsol Multiphysics programında simülasyon çalışmaları gerçekleştirilmiştir. Simülasyon sonrasında taramalı elektron mikroskopisi (SEM) ve bilgisayarlı mikro-tomografi (mikro-CT) analizi ile karakterizasyonları gerçekleştirilen Na-Y Zeolit içerikli hidrojellerin hem kesikli deney koşullarında hem de geliştirilen mikroakışkan sistemde sürekli modda simüle kan sıvısı ile yapılan protein bağlı indoksil sülfat toksininin detoksifikasyonu incelenmiştir. Geliştirilen bu mikroakışkan tasarımın, klinikte kronik böbrek hastalarının kanında biriken proteine bağlı toksinlerin uzaklaştııılmasını sağlayabilecek yenilikçi yöntemler geliştirilmesine katkı sağlayacağı düşünülmektedir.

Anahtar Kelimeler: İndoksil sülfat, Mikroakışkan platform, Adsorpsiyon, Simülasyon, Proteine bağlı üremik toksinler.

\section{Modeling of Protein-Bound Uremic Toxin Adsorption in a Microfluidic Platform}

\begin{abstract}
This study aims to develop a microfluidic platform that can be integrated into the hemodialysis system to find a solution to the uremic toxicity problem of chronic kidney patients. The hypothesis was tested which was the adsorption of one of the protein-bound uremic toxins in the blood, Indoxyl Sulfate (IS), can be achieved through the TEOS-PEO hydrogel, synthesized by sol-gel method and functionalized with Na-Y Zeolite, within the microfluidic chip. An S-shaped microchannel was designed with the Solidworks program, and simulation studies were carried out in the Comsol program. After the simulation studies, the detoxification of proteinbound indoxyl sulfate toxin from simulated blood fluid of Na-Y Zeolite-containing hydrogels, which were characterized by scanning electron microscopy and computerized micro-tomography analysis, was investigated both in batch conditions and in continuous mode in the developed microfluidic system. It is thought that this microfluidic design will contribute to the development of innovative methods that can remove protein-bound toxins that accumulate in the blood of chronic kidney patients in the clinic.
\end{abstract}

Keywords: Indoxyl sulfate, Microfluidic platform, Adsorption, Simulation, Protein-bound uremic toxins.

\footnotetext{
* Sorumlu Yazar: ozlem.yesil.celiktas@ege.edu.tr
} 


\section{Giriş}

Küresel popülasyonun yüzde 10'unu etkileyen ve her y1l bir milyondan fazla ölümden sorumlu olan kronik böbrek hastalığ $(\mathrm{KBH})$ ülkemizde ve dünyada önemli bir halk sağlığ1 sorunu haline gelmiştir. KBH, böbreklerin hasarlı olduğu veya sağlıklı böbreklerin kanı filtre edemediği glomerül filtrasyon hızının 60 $\mathrm{mL} / \mathrm{dak} / 1.73 \mathrm{~m}^{2}$ 'den düşük olduğu durumdur (Eyüpoğlu, 2020; Krieter ve diğerleri, 2010). Vücuttan atılması gereken çok sayıda toksik bileşikten bazıları biyolojik fonksiyonlarla negatif etkileşime girer ve bu maddeler üremik toksinler olarak adlandırılırlar (Vanholder ve diğerleri, 2014).

Üremik toksinler, boyutlarına veya özelliklerine göre genellikle üç ana gruba ayrılmaktadırlar. İlk grup 500 Da'dan daha düşük moleküler ağırlıklı (Mw), suda çözünür küçük moleküllerden oluşmaktadır. Bu gruptaki kreatinin ve üre gibi moleküller, geleneksel olarak "düşük-akılı" diyaliz membranları kullanılarak hemodiyaliz gibi difüzyon temelli membran tedavisi ile kandan iyi bir şekilde uzaklaştırılırlar. İkinci toksin grubu, moleküler ağırlığı daha yüksek olan orta moleküler ağırlıklı toksinlerden oluşurken, üremik toksinlerin üçüncü grubu ise insan kanındaki serum albüminine (HSA) bağlı çözünen maddelerden oluşan proteine bağlı toksinler, PBUT'dır). Hem yüksek-akılı hem de düşük-akılı diyaliz membranları albümini kan içerisinde tutmak için tasarlandığından, proteine bağlı toksinlerin sadece serbest kısmı (albümine bağlı olmayan) hemodiyaliz ve hemofiltrasyon ile giderilebilmektedirler (Vanholder ve diğerleri, 2012). PBUT'ların albümin'e yüksek bağlanma özellikleri nedeniyle difüzyonla uzaklaştırılması sağlanamamaktadır (Davenport, 2014).

Mikroakışkan teknolojisindeki gelişmeler, giyilebilir diyalizerler olan giyilebilir yapay böbrek (Wearable Artificial Kidney: WAK), Vicenza giyilebilir yapay böbrek (ViWAK), otomatize giyilebilir yapay böbrek (Automated Wearable Artificial Kidney: AWAK) ve insan nefron filtresi (Human Nephron Filter: HNF) gibi çok çeşitli minyatür tıbbi cihazların keşfine olanak sağlamış (Armignacco ve diğerleri, 2015) ve ayrıca geleneksel hastane merkezli kan arıtımı ile ilgili bazı sorunların ele alınmasını teşvik etmiştir (Gura ve diğerleri, 2016). Mikroakışkan hemodiyaliz teknikleri, portatiflik ve giyilebilirlik avantajlarının yanı sıra klinik hastane merkezli kan saflaştırmayı ev içi hemodiyaliz ile değiştirebilme potansiyellerinden dolayı kronik böbrek hastalığı tedavisinde büyük ilgi görmektedirler. Bu sistemlerin hem serbest üremik toksinleri hem de proteine bağlı üremik toksinleri detoksifiye edebilmeleri için yeni çalışmalar yapılmaktadır.

Kanın diyaliz işlemi sırasında albüminin uzaklaştırılması, albümin sentez hızı ve katabolizması, intra ve ekstra vasküler kompartmanlar arasındaki albümin dağılımı ve patolojik koşullar altındaki eksternal kayıp gibi birçok faktörden etkilendiğinden, serum albümin konsantrasyonunda hafif bir azalmaya yol açmaktadır (Zweigart, Boschetti-de-Fierro, Neubauer, Storr, Böhler ve Krause, 2017). Hasta toleransı açısından bir diyalizörden uzaklaştırılabilecek albümin sınırları hakkında, farklı tedavi modaliteleri için uzaklaştırılan albümin miktarlarına dair farklı açıklamalar mevcuttur. Örneğin, 24 aylık bir süre boyunca 17 stabil periton diyalizi hastasında serum albümin konsantrasyonunda günde 5-7 g civarında küçük ve anlamlı olmayan bir düşüş gözlemlenmiştir (Caravaca, Arrobas ve Dominguez, 2000). Konvansiyonel yüksek-akılı membranlarla yapılan hemodiyaliz işlemlerinde ise albümin kaybının, genellikle membran malzemesi ve yüzey alanına bağlı olarak 4 saatlik işlem başına 0-2 g aralığında olduğu rapor edilmiştir (Zweigart ve diğerleri, 2017; Floege ve diğerleri, 1989). Online hemodiafiltrasyon modalitesinde, albümin giderimi işlem başına 1-3 g arasında değişirken (Zweigart ve diğerleri, 2017; Floege ve diğerleri, 1989), bu işlem sırasında değişen ultrafiltrasyon oranlarına veya geleneksel yüksek-akılı membranların kullanıldı ğı hemodiafiltrasyon sistemlerindeki "itme/çekme" modalitesine bağlı olarak albümin gideriminin işlem başına 2.2-7 g arasında değişebildiği bilinmektedir (Shinzato ve diğerleri, 1996; Ikizler ve diğerleri, 1994; Zweigart ve diğerleri, 2017). Diyalizörlerin tekrarlı kullanımıyla da protein uzaklaştırma seviyeleri tedavi başına 10-12 g'a çıkarak serum albümin konsantrasyonunda önemli bir azalmayı işaret etmektedir (Kaplan ve diğerleri, 1995).

Hemodiafiltrasyon modlarında kullanılan farklı diyalizerler olan FDY 210 ve Evodial için 4 saatlik seans başına sırasıyla 2.2-15.5 g ve $0.48 \mathrm{~g}$ aralığında albümin kayıpları (Zweigart ve diğerleri, 2017) söz konusu iken, yaygın olarak kullanılan diyaliz sistemlerini inceleyen daha güncel bir çalışmada ise $3.0 \pm 2.4$ - $4.3 \pm 3.5 \mathrm{~g}$ aralığında albüminin diyaliz sırasında kandan uzaklaştırılabildiğini ifade edilmiştir (Maduel ve diğerleri, 2014).

Bu çalışmada, kronik böbrek hastalarının kullanabileceği ve proteine bağlı üremik toksinlerin kandan detoksifikasyonunu sağlayabilecek zeolit içeren bir hidrojelle yüklü bir mikroakışkan platformun geliştirilmesi hedeflenmiştir. Zeolitler kristalin yapılı aluminosilikat minerallerdir ve zeolit ile fonksiyonelleştirilen polimerik membran matrislerinin ayırma performanslarında artış sağlanabildiği bilinmektedir (Tırnakçı, Salt, Salt, ve Keyf, 2020). Geliştirilen mikroakışkan çipin bugün klinikte kullanılan diyaliz sistemlerinde entegre edilebildiği takdirde, kan dolaşımından uzaklaştırılmaları veproteine-bağlı olmaları nedeniyle kısıtlı olan protein-bağlı üremik toksinlerin biosorpsiyonunun kandaki albümin protein miktarı korunarak sağlanabileceği düşünülmektedir.

\section{Materyal ve Metot}

\subsection{D CAD Modeli Çalışmaları}

İndoksil sülfat (IS) maddesinin mikroçip içerisinde adsorbsiyonunun simüle edilebilmesi için yapılan modelleme çalışmalarında S-şekilli mikro-akışkan sistem tasarlanmıştır. $\mathrm{Bu}$ sistemin avantajı, tasarımı sayesinde, mikroakışkanın kanallardaki kalış süresini arttırmasıdır. Suda çözünmeyen gözenekli bir yapı olan ve kan üremik toksinlerini adsorbe edebilen Na-Y Zeolit adsorbantı ile yüklenmiş $\mathrm{S}$ şekilli mikroakışkan sistemin tasarımı Solid Works programı (Dassault Systèmes, SOLIDWORKS Corp., Fransa) kullanılarak yapılmıştır. Toplam kanal hacmi ve kesit alanı sırasıyla $100 \mu \mathrm{L}$ ve $0.25 \times 10^{-6} \mathrm{~m}^{2}$ olarak hesaplanmıştır. Mikrokanallarda genişlik ve derinlik $500 \mu \mathrm{m}$ iken, üremik toksin ve adsorban madde arasındaki fiziksel etkileşimi arttırmak için çip içerisinde alıkonma süresinin daha uzun olması amaçlanmış, bu sebeple kanalın uzunluğu $40 \mathrm{~cm}$ olarak belirlenmiştir (Şekil 1). 


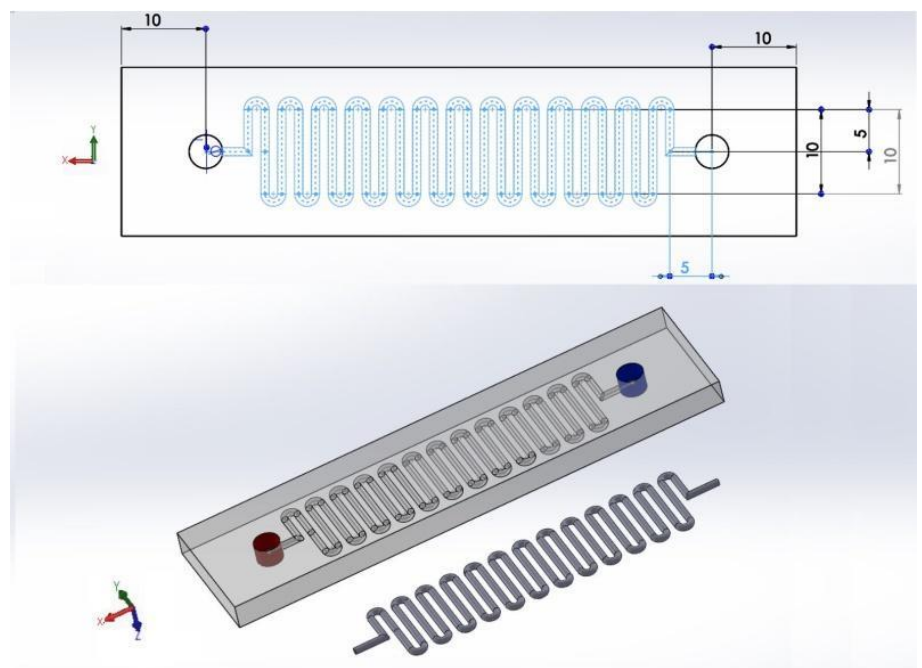

Şekil 1. Platform iç tasarımı ve ölçüleri

\subsection{Simülasyon Çalışmaları}

Modelin simülasyonu için Comsol programı kullanılmıştır. Comsol programındaki "Transport of diluted species in porous media" modeli üzerinden çipe giren simüle kandaki IS maddesi miktarının zamana bağlı olarak değişimi modellenmiştir. Simülasyon parametreleri kan akış hızı, kanın viskozitesi, kanın zeolit içerisindeki difüzyon katsayısı, IS konsantrasyonu ve zeolit adsorbanının porozitesidir. Platforma giren simüle kan sıvısının akış hızı 2-10 $\mu \mathrm{L} / \mathrm{dk}$ arasında; 4,7 ve $10 \mu \mathrm{L} / \mathrm{dk}$ olarak uygulanmıştır. Bu değerler sisteme $6.66 \mathrm{e}-8 \mathrm{~m} / \mathrm{s}, 1.16 \mathrm{e}-7 \mathrm{~m} / \mathrm{s}$ ve $1.66 \mathrm{e}-7 \mathrm{~m} / \mathrm{s}$ olarak girilmiştir. Ayrıca IS konsantrasyonu 3, 1.55 ve $0.1 \mathrm{mg} / \mathrm{dL}$ olarak uygulanmıştır. Akışkanların platformdan çıkış yaptığı bölgelerde basınç değeri program aracılığıyla $101325 \mathrm{~Pa}$ olarak girilmiştir. Simüle edilecek kan sıvısının (IS ve $50 \mathrm{mg} / \mathrm{mL}$ albümin içeren $\mathrm{pH} 7.40 .01 \mathrm{M}$ fosfat tamponlu salin: PBS) viskozitesi $0.003 \mathrm{~Pa} \cdot \mathrm{s}$ ve yoğunluğu ise $1025 \mathrm{~kg} / \mathrm{m}^{3}$; IS'ın molekül ağırlığ $0.21321 \mathrm{~kg} / \mathrm{mol}$ ve difüzyon katsayısı $1.6^{*} 10^{-9}$; mikroakışkan kanala yüklenen hidrojeldeki Na-Y Zeolit (CBV-100) materyalinin porozitesi 0.48 ve yoğunluğu ise $1.01 \mathrm{~g} / \mathrm{cm}^{3}$ olarak kabul edilmiştir. Adsorpsiyon izotermi (1) için de dağılım katsayısı $\left(\mathrm{K}_{\mathrm{D}}\right) 0.16 \mathrm{~m}^{3} / \mathrm{kg}$ ve dispersiyon katsayısı (E) $4.11 \mathrm{e}-6 \mathrm{~m}^{2} / \mathrm{s}$ olarak kabul edilmiştir. Genel anlamda ise "c" konsantrasyonu, "L" kanal uzunluğunu ve "t" zamanı simgelemektedir.

$\left(1+\frac{K_{D} \rho}{\eta}\right) \frac{d c}{d t}=-u_{L} \frac{d c}{d L}+E \frac{d^{2} c}{d L^{2}}+r \quad u_{L}$ in $\frac{m}{\text { time }}$

$\mathrm{K}_{\mathrm{D}}$ : Dağılım katsayısı

E: Dispersiyon katsayısı

$\mathrm{u}_{\mathrm{L}}$ : Hacimsel akış hızı

$\rho$ : Adsorban yoğunluğu

$\eta$ : Adsorban viskozitesi

\subsection{Na-Y zeolit içerikli hidrojelin hazırlanması}

Sol-Jel metodu ile sentezlenen TEOS (tetraethoxysilane) PEO (polyethylene oxide) hidrojelleri, 0-50-100 mg zeolit içerecek şekilde her bir parti için $0.125 \mathrm{~mL}$ TEOS hidrolizatı ve $0.250 \mathrm{~mL}$ PEO solüsyonu Şekil 2'de görülen Luer Lock şırıngalar içerisinde birkaç dakika vortekslenerek karıştırılmış ve ardından dik konumda $45 \mathrm{dk}$ jelleşmeye birakılarak hazırlanmıştır. Mikrokanala yüklenecek hidrojel de aynı şekilde hazırlanmış ve $45 \mathrm{dk}$ boyunca şırıngada jelleşmeye bırakıldıktan sonra homojen form gözlemlendiğinde mikrokanala enjektör yardımıyla transfer edilerek mikroakışkan çip içerisine yüklenmiştir.

TEOS hidrolizasyonu için, silan prekürsörü olan TEOS (tetraetoksisilan), Ultrasaf su ve $\mathrm{HCl}(\% 0.1, \mathrm{v} / \mathrm{v})$ hacimce 5.58/1.9/1 oranında 2.5 saat süresince oda sicaklığında karıştırılmıştır (Yesil-Celiktas, Cumana ve Smirnova, 2013). PEO (polietilen oksit) solüsyonu ise $\mathrm{Na}-\mathrm{Ca}$ asetat tamponu $(\mathrm{pH}$ 4.8) içerisinde $80 \mathrm{mg} / \mathrm{mL}$ konsantrasyonda PEO çözülmesi ile elde edilmiştir. Jelleşme sonrası Şekil 2'de görüldüğü gibi şırınga ağızları kesilmiş ve üzeri saf TEOS ile kaplanarak $+4^{\circ} \mathrm{C}^{\text {'de }} 24$ saat yaşlandırmaya bırakılmıştır. Ardından şırınga pistonu itilerek kesikli adsorpsiyon denemelerinde kullanılacak monolitler elde edilmiştir. Mikrokanaldaki jelin yaşlandırılması ise mikrokanal giriş ve çıkış kısımlarının saf TEOS ile kaplanması ve aynı şekilde $+4^{\circ} \mathrm{C}$ 'de 24 saat muhafaza edilmesi sonrasında gerçekleştirilmiştir. Sentezlenen hidrojeller, taramalı elektron mükroskobu (SEM) ve bilgisayar destekli mikro tomografi (mikro-CT) ile karakterize edilmiştir.

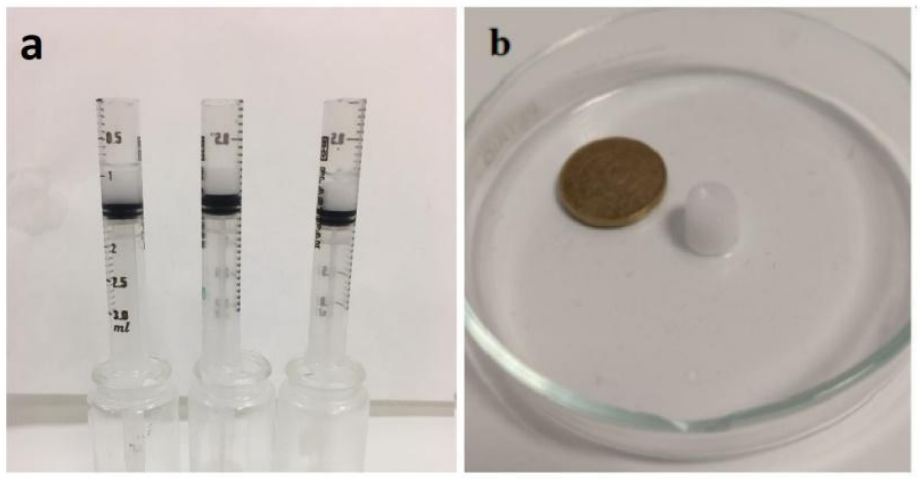

Şekil 2. Luer Lock şırıngalar içerisinde Zeolit-Jel monolitlerinin hazırlanması (a) ve Zeolit içeren jel monolitinin yaşlandırma sonrasl görüntüsü (b)

\subsection{Mikroakışkan Platformun Hazırlanması}

Mikroakışkan çipin kalıp bazlı yöntem ile fabrikasyonunun gerçekleştirilebilmesi için polidimetilsiloksan (PDMS) polimeri kullanılmıştır. S-şekilli kanalları oluşturmak için kullanılacak kalıbın üzerine PDMS polimeri ve aktifleştiricisi üretici firmanın önerdiği şekilde karıştırılarak paslanmaz çelik kalıplara dökülmüştür (Şekil 3a). Daha sonra polimer karışımında oluşan kabarcıkların yok edilmesi için karışım vakum altında $15 \mathrm{dk}$ bekletilmiş ve kabarcıkları uzaklaştırılmış PDMS jeller $80^{\circ} \mathrm{C}$ 'de 2 saat bekletilerek sertleştirilmiştir. Kalıptan çıkarılan sertleşmiş PDMS polimer mikrokanalların Plasma Cleaner cihazı yardımıyla yüzeyleri aktifleştirildikten sonra lamlar ile birleştirilmiş (Şekil 3b) ve akışa bağlanmaya hazır hale gelmiştir.

\subsection{Kesikli Adsorpsiyon Denemeleri}

Çip denemelerine geçilmeden önce uygun parametrelerin belirlenmesi için öncesinde kesikli koşullarda adsorpsiyon denemeleri yapılmıştır. PBS içerisine kronik böbrek hastalarının kanında bulunan konsantrasyonda $(50 \mathrm{mg} / \mathrm{mL})$ sığır serum albümini ve $0.03 \mathrm{mg} / \mathrm{mL}$ konsantrasyonda IS eklenerek gece boyu karıştırıcı (200 rpm) üzerinde $37^{\circ} \mathrm{C}$ 'de inkübe edilmiş ve böylelikle toksinlerin albümine bağlanmaları sağlanmıştır. $\mathrm{Bu}$ 
şekilde hazırlanan simüle kan sıvısının $2.4 \mathrm{~mL}$ 'si bir behere alınarak içerisine şırıngadan alınan monolit eklenmiş ve 4 saat boyunca manyetik karıştırıcıda (200 rpm) karıştırılmıştır. Belirli zaman aralıklarında alınan örneklerde, albümine bağlı IS toksini ile serbest halde bulunan IS'ın ayrılması için 100000 rpm hıza çıkabilen ultrasantrifüj kullanılmıştır. $100000 \mathrm{rpm}$ de 2 saat süresince ultrasantrifüjün ardından üstte kalan fazda serbest IS, altta kalan pellet kısmında proteine bağlı olan IS molekülleri bulunmaktadır. Üst fazdaki süpernatantın $30 \mu \mathrm{L}$ 'sinde bulunan serbest IS konsantrasyonu nanodrop ile ölçülmüştür.
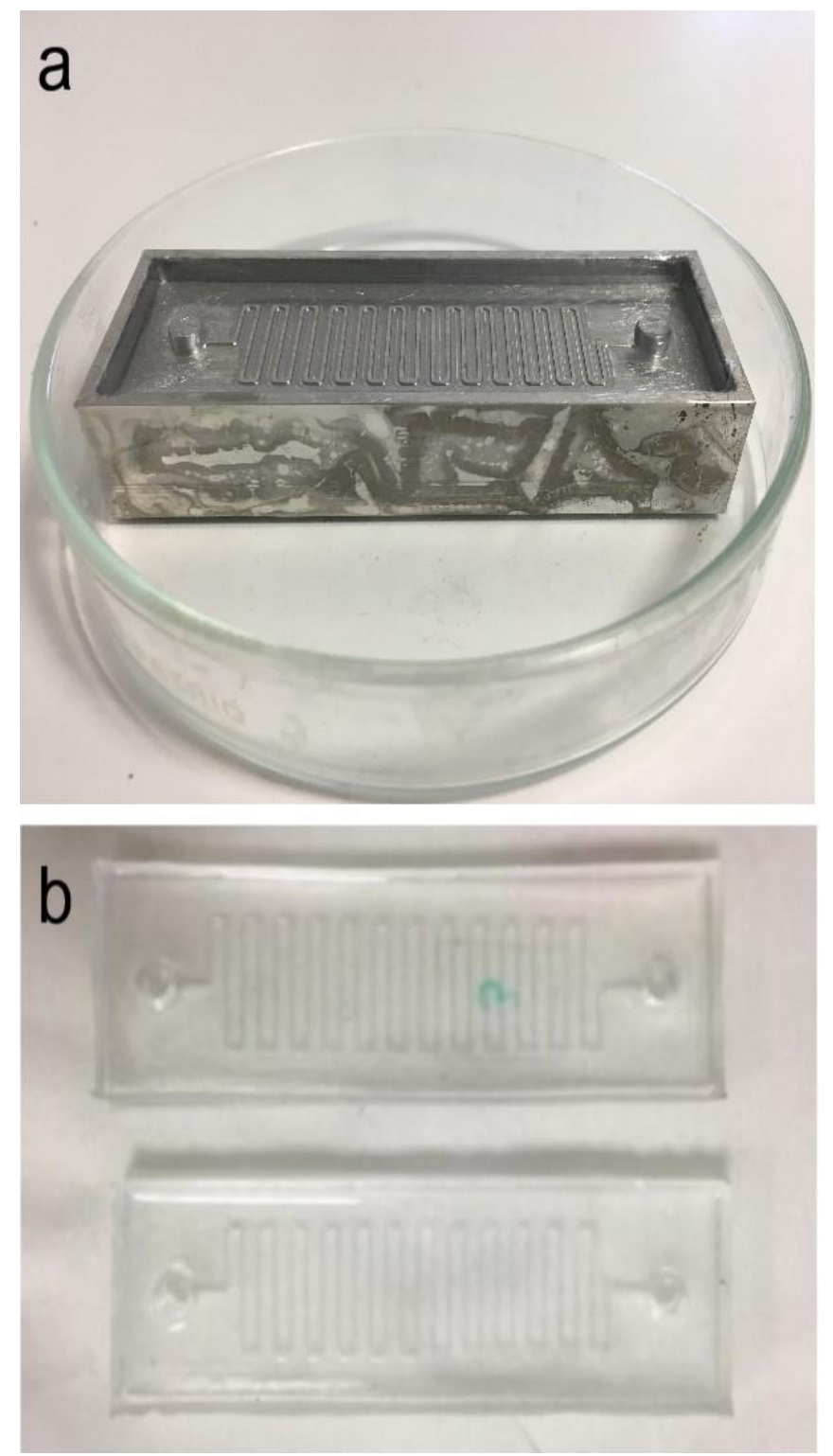

Şekil 3. Kalıba dökülmüş PDMS polimeri (a) ve PDMS polimerinden hazırlanmış, lamlar ile kapatılmış mikroçipler (b)

\subsection{Mikroakışkan Platformda Adsorpsiyon Denemeleri}

Mikrokanala yüklenen farklı miktarda zeolit içeren hidrojellerin yaşlandırılmalarını takiben, mikroçip giriş ve çıkış kısımlarına sıcak silikon yardımı ile bağlantı boruları takılmış ve bu boruların diğer uçları ise şırınga pompalarındaki simüle kan içeren şırıngalara bağlanmıştır. Mikrokanaldaki akış hızı 10 $\mu \mathrm{L} / \mathrm{dk}$ ve akış süresi 4 saat olacak şekilde ayarlanarak akış e-ISSN: 2148-2683 başlatılmıştır. İnsan vücudu simüle edilmek istendiğinden mikroakışkan çipler ile sürekli modda gerçekleştirilen adsorpsiyon denemeleri $37^{\circ} \mathrm{C}$ sicaklıktaki etüv içerisinde gerçekleştirilmiştir (Şekil 4). Mikroçiplerin çıkış kanallarından toplanan simüle kan sıvısı ependorflarda toplanmıştır.

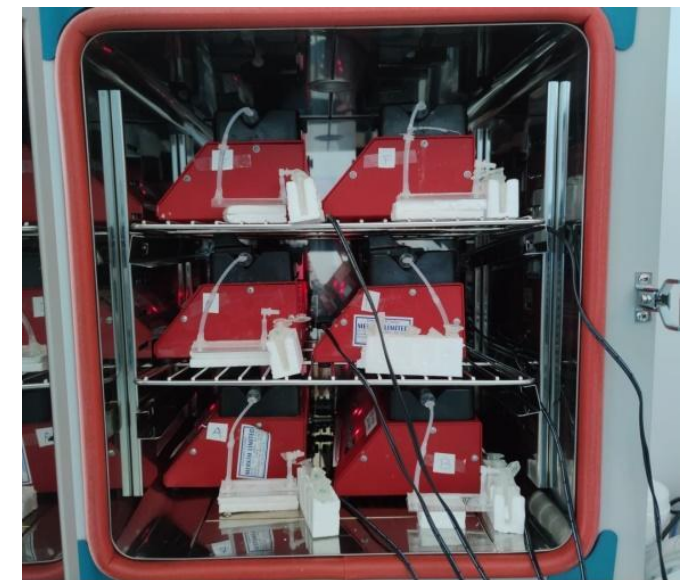

Şekil 4. Inkübatör içerisine yerleştirilmiş şırınga pompalarına bağlanmış mikroakışkan çiplerde gerçekleştirilen adsorpsiyon denemeleri

\section{Araştırma Sonuçları ve Tartışma}

\subsection{Simülasyon Çıktıları}

Yapılan simülasyon çalışmasında çipin farklı noktalarındaki konsantrasyon değişiminin zamana bağlı grafiği Comsol Multiphysics programı aracılığıyla çizilmiştir. Çipin altı farklı noktasında IS konsantrasyonunun incelendiği grafikte (Şekil 5), IS içeren simüle kan sıvısı mikrokanala girdikten hemen sonra kanal içerisindeki zeolit ile fonksiyonelleştirilmiş TEOS-PEO hidrojeline IS toksininin adsorpsiyonlanması sebebiyle 1 numaralı noktada IS konsantrasyonunda çok hızlı artış gözlemlenmektedir. Kanalda ilerleyen simüle kan sıvısındaki IS'ın adsorpsiyonlanarak konsantrasyonunun düşmesi nedeniyle, çipin orta noktaları olan 2, 3, 4 ve 5 numaralı noktalardaki adsorplanmış IS konsantrasyonları da giriş noktasına olan uzaklıkları ile orantılı olarak düşmektedir.
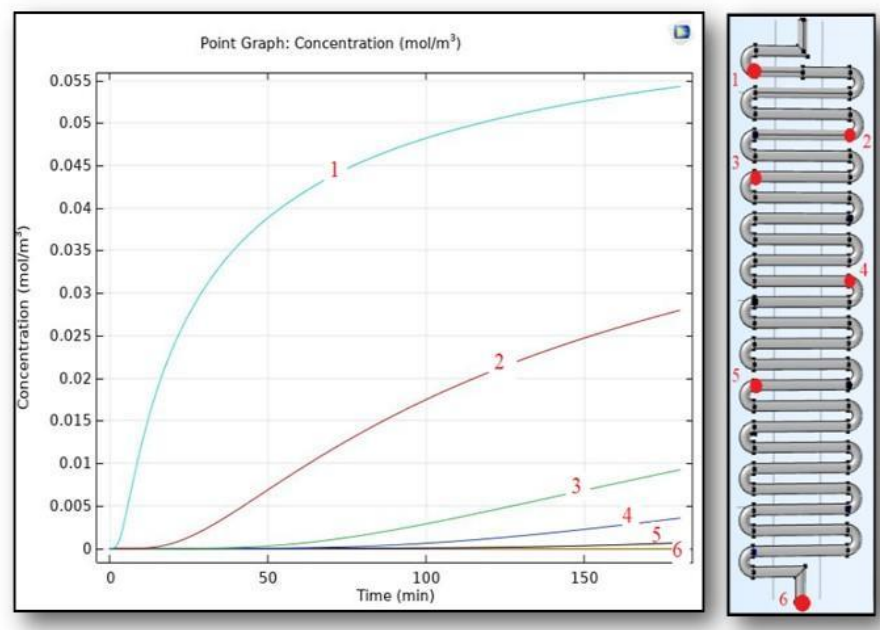

Şekil 5. Simulasyon sonucunda programdan elde edilen mikroçipin farklı noktalarına ait zamana bă̆ll IS konsantrasyonu değişimi (sol) ve çip üzerinde seçilen noktalar (să) 
Comsol programında yapılan simülasyon çalışmalarında farklı akış hızları ve farklı IS konsantrasyonları denenmiştir. Farklı konsantrasyonlarda $(3.0,1.55$ ve $0.1 \mathrm{mg} / \mathrm{dL})$ IS içeren hidrojeller için $10 \mu \mathrm{L} / \mathrm{dk}$ sabit akış ile gerçekleşen simülasyonlar sonucunda belirlenen akış hızları aralığında IS adsorpsiyon miktarında bir değişim gerçekleşmediği görülmüştür (Şekil $6 \mathrm{a}$, b, c). Ayrıca simüle kan sıvısının $40 \mathrm{~cm}$ toplam uzunluktaki mikrokanala girmesinden çok kısa bir süre sonra henüz kanalın girişine yakın bölgede IS konsantrasyonunun sıfira yaklaştığı görülmüştür (Şekil 6). IS konsantrasyonu sabit tutularak $(3 \mathrm{mg} / \mathrm{dL})$ farklı akış hızlarında (4, 7 ve $10 \mu \mathrm{L} / \mathrm{dk})$ gerçekleştirilen denemelerde de benzer şekilde henüz kanalın girişine çok yakın bir bölgede IS konsantrasyonunun sıfira yaklaştığı görülmüştür (Şekil $6 \mathrm{~d}$, e, f).

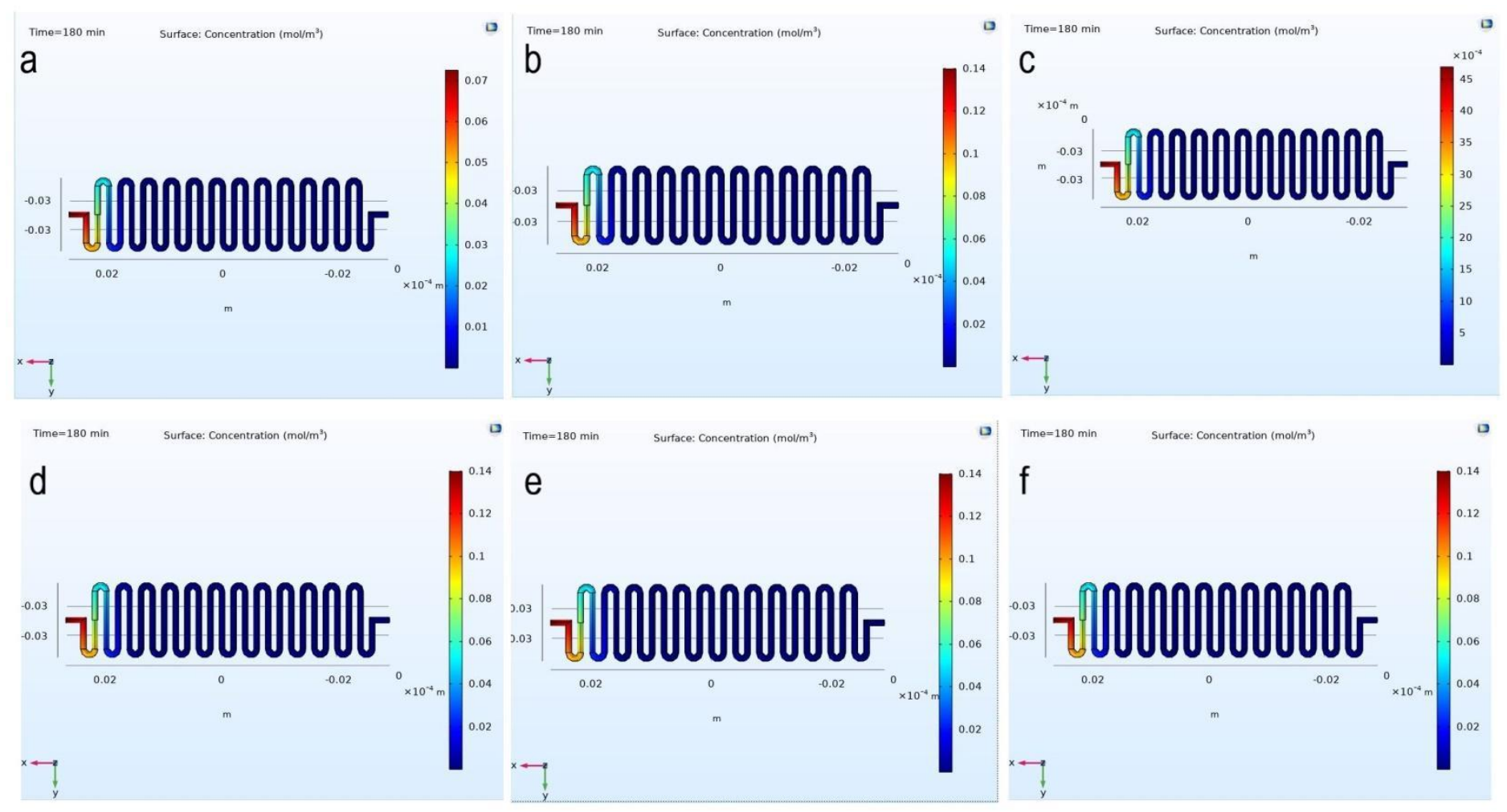

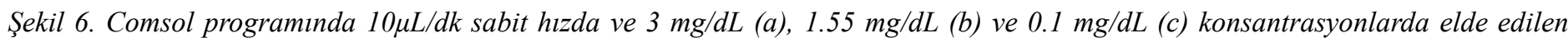
simülasyonlar ile $3 \mathrm{mg} / \mathrm{dL}$ sabit IS konsantrasyonunda simüle kan sıvısının kullanıldiğı $10 \mu L / d k(d) 7 \mu L / d k(e)$ ve $4 \mu L / d k$ (f) akıs hızında elde edilen simülasyonlar.

\subsection{Na-Y Zeolit İçerikli TEOS-PEO Hidrojelin Karakterizasyon Çalışmaları}

Sentezlenen zeolit içeren/içermeyen TEOS-PEO hidrojellerinin yüzey morfolojisini görmek ve por çaplarının boyutlarını belirleyebilmek için SEM ve micro-CT görüntüleri incelenmiştir. Jel içerisinde $500^{\circ} \mathrm{C}$ 'de gece boyu kalsinize edilmiş zeolit bulunmaktadır ve Şekil 7'de görüldüğü gibi adsorbsiyon için avantaj sağlayabilecek por yapılarına sahip olduğu görülmektedir. $100 \mathrm{mg} \mathrm{Na}$-Y Zeolit içeren jellerde (Şekil 7A), $50 \mathrm{mg} \mathrm{Na-Y} \mathrm{Zeolit} \mathrm{içeren} \mathrm{jellere} \mathrm{(Şekil} \mathrm{7B)} \mathrm{göre} \mathrm{porları}$ temsil eden kırmızı-yeşil aralığındaki renklerde artış meydana gelmesi, artan zeolit miktarının poroziteye olumlu yönde katk1 sağladığını ortaya çıkarmıştır. TEOS-PEO hidrojellerinin içerisine eklenen $\mathrm{Na}-\mathrm{Y}$ Zeolit konsantrasyonu artışının hidro- jeldeki por yapısını olumlu etkilediği ve daha porlu bir yapıya olanak sağladığı görülmektedir ve gelişmiş por yapısı da PBUT (IS toksini) adsorbsiyonu açısından avantaj sağlamaktadır.

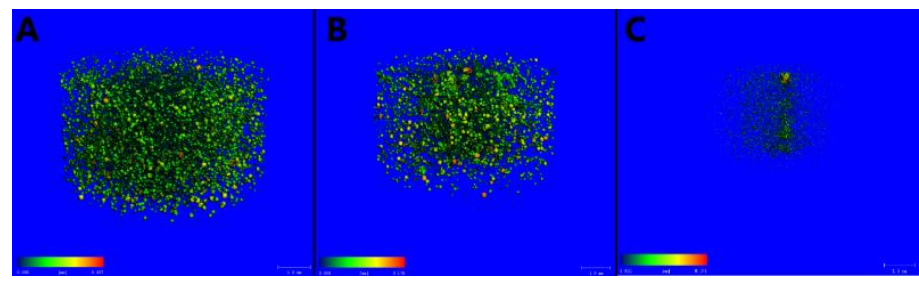

Şekil 7. Micro-CT por dağılımı görüntüleri $100 \mathrm{mg} \mathrm{Na-Y} \mathrm{Zeolit}$ içeren hidrojel (A,) $50 \mathrm{mg} \mathrm{Na-Y} \mathrm{Zeolit} \mathrm{içeren} \mathrm{hidrojel} \mathrm{(B)} \mathrm{ve} \mathrm{Na-}$ $Y$ Zeolit içermeyen hidrojel $(C)$ 
Mikro-CT analizi ile elde edilen kantitatif por dağıılımı sonuçları Şekil 8'de görülmektedir. Zeolit katkısı olmaksızın sentezlenen TEOS-PEO hidrojellerindeki porların yaklaşı olarak \%60'1 $0.0148 \mathrm{~mm}$ çapındayken, monolit başına $50 \mathrm{mg}$ zeolit ile fonksiyonelleştirilmiş hidrojellerde por çaplarının genişleyerek \%19'nun $0.074 \mathrm{~mm}, \% 18$ 'nin $0.0592 \mathrm{~mm}$ ve $\% 13$ 'nün de $0.0888 \mathrm{~mm}$ ortalama çapa sahip oldukları görülmektedir (Şekil 8). Ayrıca Şekil 7 ile benzer olarak, monolit başına $100 \mathrm{mg}$ 'a artan Zeolit konsantrasyonunda $50 \mathrm{mg}$ Zeolit içerenlere göre en yüksek por dağıllım çubukları olan $0.1184 \mathrm{~mm}, 0.1332 \mathrm{~mm}$ ve $0.148 \mathrm{~mm}$ bölgelerinde \% por yoğunlukları daha yüksektir.
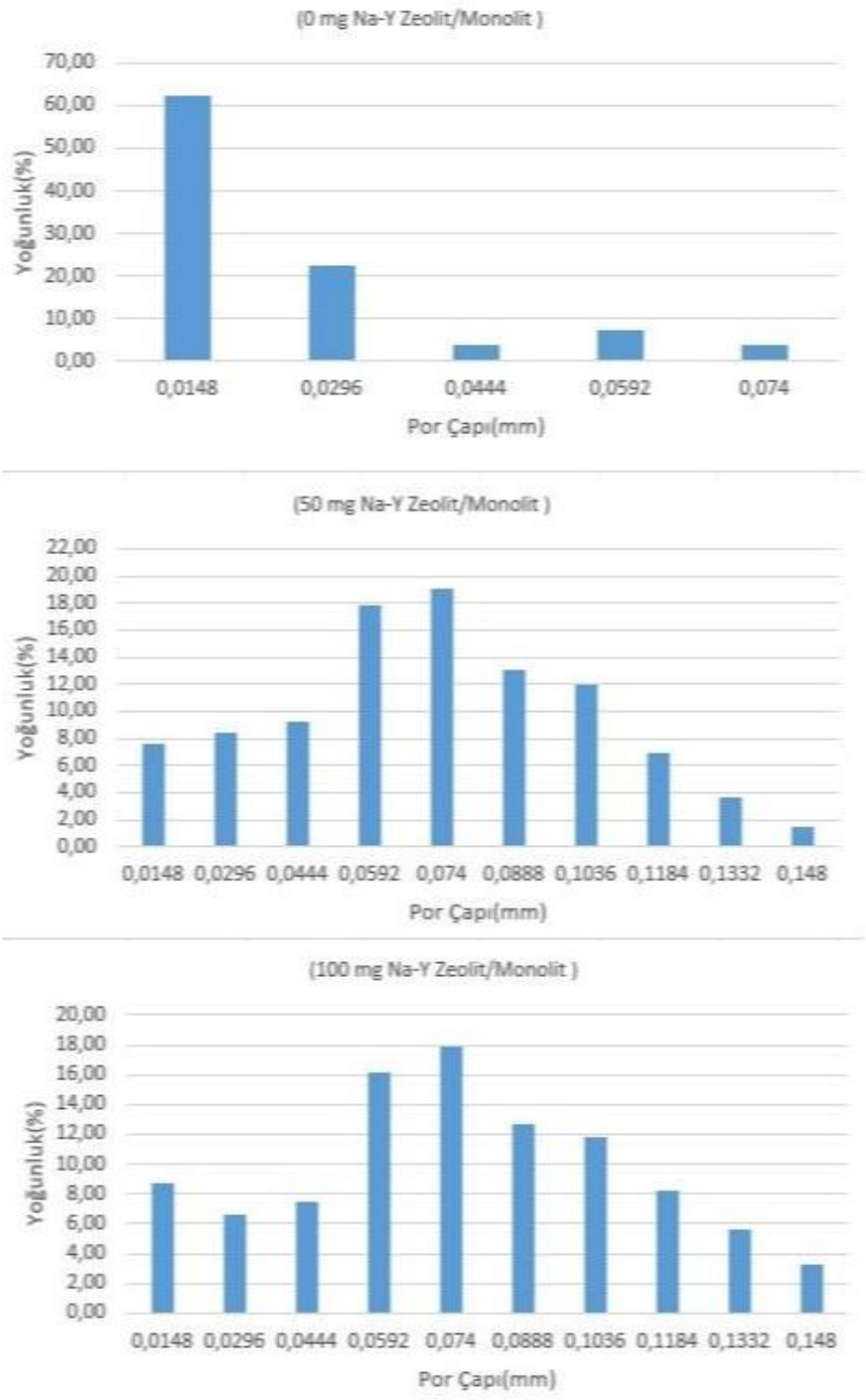

Şekil 8. Zeolit içermeyen ve farklı konsantrasyonlarda zeolit içeren hidrojellerde ortalama por çapı $(\mathrm{mm})$ dağgllım grafikleri
Örneklerin yüzey morfolojilerinin incelenmesi için Quanta 200 FEI SEM-EDX elektron mikroskobu kullanılmıştır. Açıkça görülebilen kristallerden ayrı olarak neredeyse homojen bir matris, mikrokristalin fazlar ve amorf kütlenin bir karışımı olduğu gözlenmektedir (Şekil 9).
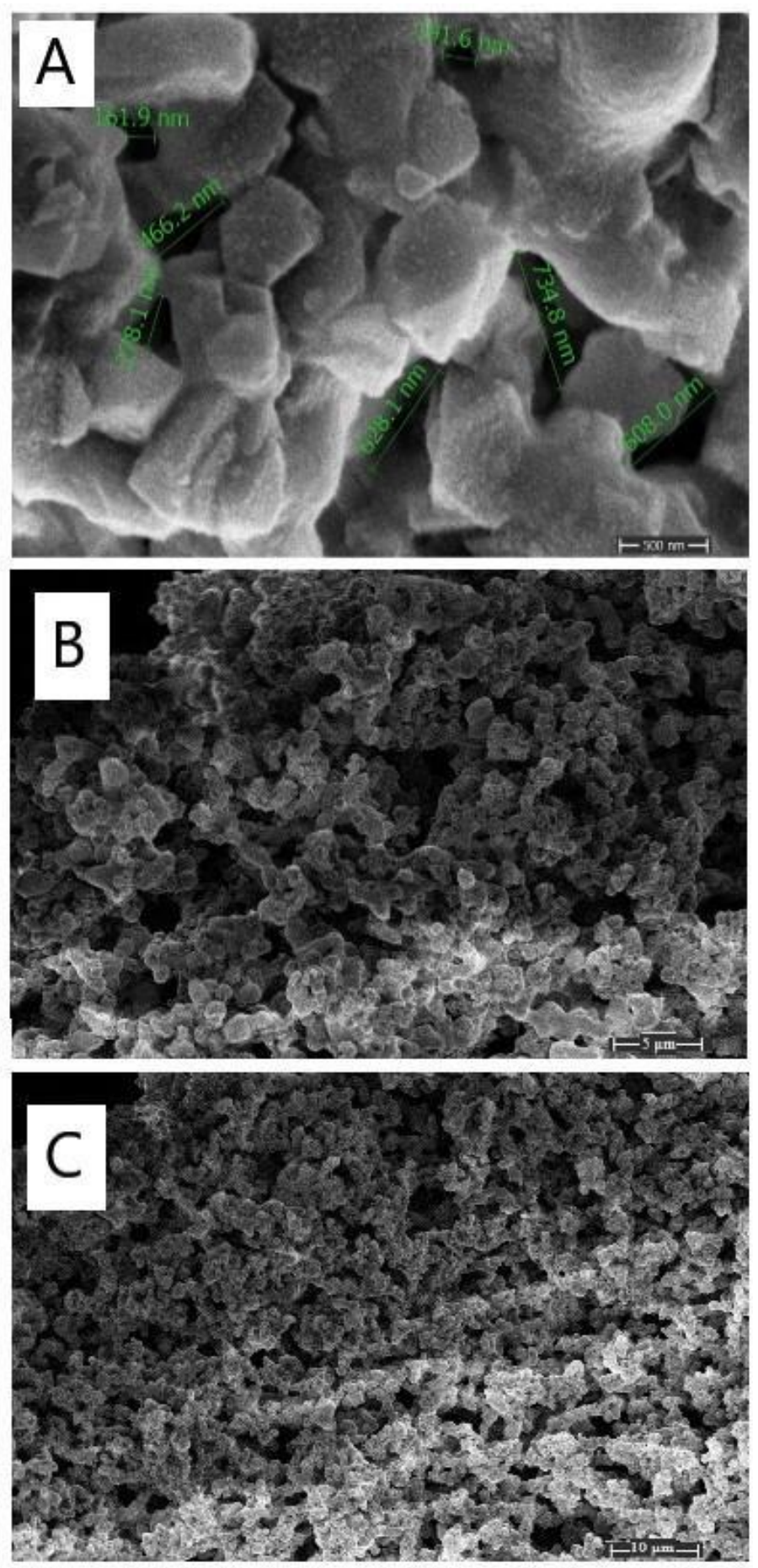

Şekil 9. Na-Y Zeolit-Jel Monolitleri SEM görüntüleri ölçek 500 $\mathrm{nm}$ (a), 5 um (b) ve $10 \mu \mathrm{m}$ (c) 


\subsection{Monolitlerle Yapılan Kesikli Adsorpsiyon Denemeleri}

Albümine bağlı üremik toksinlerin kesikli koşullarda adsorbsiyonlarının belirlenebilmesi için manyetik karıștırıcı üzerinde karıştırmalı olarak monolit hidrojellerle adsorpsiyon denemeleri gerçekleştirilmiş ve simüle kan sıvısındaki IS konsantrasyonunun zamana bağlı değișimi spektroskopik bir yöntem olan nanodrop cihazı ile analiz edilmiştir. Böylelikle, mikroakışkan çip sistemi içerisinde gerçekleştirilmesi planlanan detoksifikasyon işlemi hakkında ön fikir edinilmesi sağlanmıştır. Başlangıç IS konsantrasyonu $0.03 \mathrm{mg} / \mathrm{mL}$ olarak belirlenmiş ve 4 saatin (ortalama bir diyaliz muamelesi süresi) sonunda $100 \mathrm{mg}$ ve $50 \mathrm{mg}$ Zeolit içeren hidrojeller ile Zeolit içermeyen TEOSPEO monolit hidrojellerin denendiği kesikli adsorpsiyon denemelerinde simüle kan sıvısında kalan IS konsantrasyonları sırasiyla $0.0152,0.0137$ ve $0.0134 \mathrm{mg} / \mathrm{mL}$ olarak bulunmuştur (Şekil 10). Monolit başına $100 \mathrm{mg}$ Zeolit içeren jellerle yapıla denemelerde, 2 . ve 3 . saatlerde simüle kan sivisinda adsorplanmadan kalan IS konsantrasyonları, zeolit içermeyen veya $50 \mathrm{mg}$ konsantrasyonda Zeolit içeren jellerden daha düşük olarak ölçülmüş̧tür. Ayrıca, $50 \mathrm{mg}$ konsantrasyonda Zeolit içeren jellerde adsorplanmadan kalan IS konsantrasyonunun zeolit içermeyen jellerden daha düşük olması da hedeflendiği üzere Zeolit katkısının IS adsorpsiyonunu olumlu yönde etkilediğini ortaya çıkarmıştır. 4 saatlik denemenin sonunda bu yönelimin tersine dönerek zeolitsiz jelde adsorpsiyon devam ederken, zeolit katkılı monolit jellerin muamele edildiği simüle kan sıvısında adsorplanmadan kalan IS konsantrasyonunda ise hafif bir artış meydana gelmiştir. $\mathrm{Bu}$ durum, bu monolitlerdeki zeolit katkısının jellerin dayanımını muhtemelen olumsuz etkilediğini ve bozulmaya başlayan jellerden adsorplanmış IS moleküllerinin kaçışına olanak sağladığını düşündürmüştür.

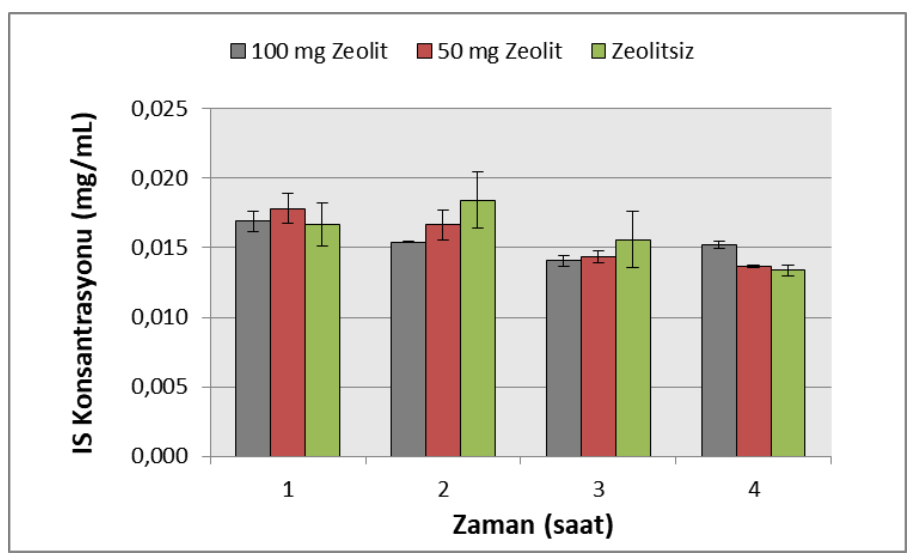

Şekil 10. Kesikli adsorpsiyon denemeleri sonrasinda IS molekülünün simüle kan içerisinde zamana bağlı konsantrasyon grafiği

\subsection{Mikroakışkan Platformda Adsorpsiyon Denemeleri}

Albümine bağlı üremik toksinlerin adsorbsiyon miktarının belirlenebilmesi için gerçekleştirilen kesikli adsorpsiyon denemelerinin ardından mikroakışkan çip denemeleri gerçekleştirilerek geliştirilen sistemin adsorbsiyon sonuçları elde edilmiştir. Saatte $600 \mu \mathrm{L}$ örnek toplanmış ve 4 saatin sonunda her bir çip için $2400 \mu \mathrm{L}$ örnek elde edilmiştir. Ependorflarda toplanan simüle kan sıvisı örnekleri, ultrasantrifüjde fraksiyonlanarak, süpernatantın en üstten alınan $30 \mu \mathrm{L}$ 'sinde bulunan serbest IS konsantrasyonu nanodrop ile ölçülmüştür (Şekil 11). Zeolit içeren hidrojellerle yüklü mikroakışkan çiplerde adsorplanmadan kanalı terk eden IS konsantrasyonu, zeolit içermeyen jellerle yüklenen mikroakışkan çiplere göre özellikle ilk saatlerde daha yüksek olarak belirlenmiştir. Beherlerdeki simüle kan sıvısı içerisinde, monolit halindeki zeolit katkılı jellerin manyetik karıştırıcı yardımıyla karıştırıldığı kesikli adsorpsiyon denemelerinde elde edilenin aksine, mikroakışkan çiplerde gerçekleştirilen adsorpsiyon denemelerinde zeolit katkılı jeller zeolit içermeyenlere göre IS adsorpsiyonunda olumlu bir artış sağlayamamıştır. Beherlerde gerçekleşen çok yönlü karışmanın aksine, mikroakışkan çiplerde tek yönlü ilerleyen simüle kan sıvısının özellikle kanalın ilk girişinde yarattığı yüksek basınç nedeniyle, dayanımlarının daha düşük olduğu düşünülen zeolit içerikli jeller ile mikrokanal iç yüzeyinin temas ettiği alandan bu sıvının sızarak çipi terk ettiği, dolayısıyla da porlara yeterince difüze olmadan sistemi terk eden simüle kan sivisından adsorplanabilen IS konsantrasyonunun daha düşük olmasına sebep olduğu sonucuna varılmıştır. Mikroakışkan çiplerden 3 saatlik süre sonunda zeolit içeren jellerle yüklü çipi terk eden simüle kan sıvısı numunelerinde adsorplanmadan kalan IS konsantrasyonunun düşmesi, ilerleyen saatlerde porlar içerisine difüze olan simüle kan sıvısı nedeniyle adsorplanabilen IS konsantrasyonunun da arttığını düşündürerek bu hipotezi desteklemiştir. 4. saatin sonunda zeolit içeren ve içermeyen jeller ile yüklü çiplerde adsorplanan IS miktarlarında önemli bir fark görülmemiştir.

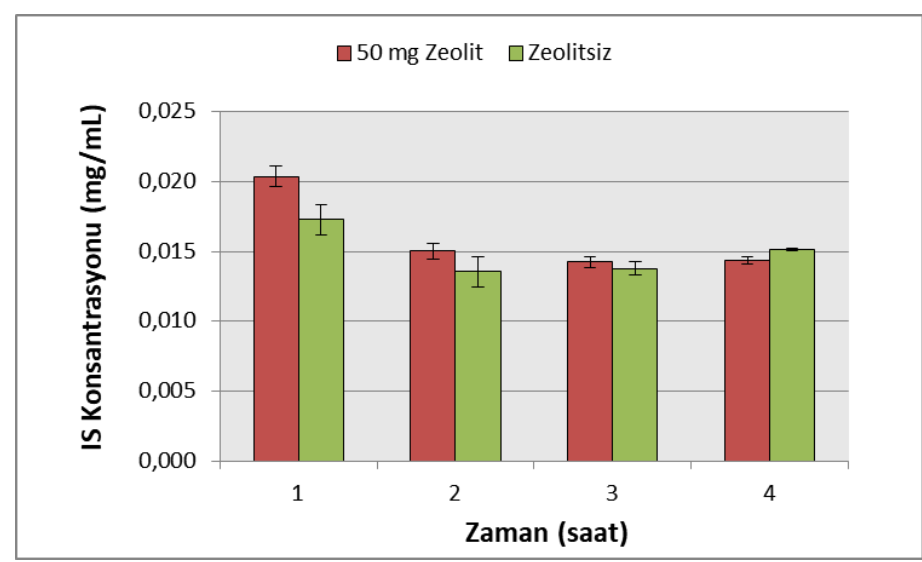

Şekil 11. Mikroakışkan çiplerle gerçekleştirilen adsorpsiyon denemeleri sonrasinda IS molekülünün simüle kan içerisinde zamana bă̆ll konsantrasyon grafiği

Proteine-bağlı bir diğer toksin olan p-cresol'ün in vitro koşullarda MFI tipi zeolit parçacıkları ile \%80-85 oranında elimine edilebildiği bildirilmiştir (Bergé-Lefranc ve diğerleri, 2012). Ancak insan serum albümini ile birlikte iken p-cresol toksinin proteine bağlanma isteği nedeniyle zeolite afinitesinin düştüğü, dolayısıyla zeolitlerin ancak serum albümini içermeyen kan ultra-filtratı için adsorbent olarak kullanılması önerilmiştir. BSA içeren simüle kan sıvısı ile gerçekleştirilen bu çalışmada ise IS adsorbsiyon verimleri Zeolit içeren ve içermeyen hidrojellerle yüklü mikroakışkan çipler için sırasıyla $\% 53.27$ ve $\% 49.78$ olarak hesaplanmıştır. Dolayısıyla Zeolit ile fonksiyonelleştirilen TEOS-PEO hidrojel ile yüklü mikroakışkan çiplerin, diyaliz sistemlerine entegrasyona çok daha uygun olduğu kanaatine varılmıştır. 


\section{Sonuç}

$\mathrm{Bu}$ çalışmada, kan temsili toksin içeren tampon çözeltinin (simüle kan sıvısı) platform içerisinde kalış süresini arttırmak ve yüzey alanını genişletmek amacıyla Solid Works çizim programı kullanılarak S-şekilli bir mikroakışkan çip tasarlanmıştır. Tasarımın optimum deneme koşullarını belirleyebilmek için, Comsol programında simülasyon yapılarak, simüle kan sıvısının kullanıldı ̆̆ detoksifikasyon denemelerine uygunluğu analiz edilmiştir. Daha sonra mikroakışkan sistem içerisine yerleştirilen Na-Y Zeolit içeren adsorban hidrojel aracılığı ile proteine bağlı bir üremik toksin (PBUT) olan indoksil sülfat adsorpsiyonunun incelenmesi öncesinde, mikrosistem ile karşılaştırma amaçlı in vitro kesikli adsorpsiyon denemeleri kurulmuştur. Belirlenen süre boyunca, simüle kan sıvısı örnekleri toplanmış ve indoksil sülfat içerikleri, UV spektrometre ve nanodrop ile analiz edilmiştir. Diyaliz hastalarının kanında bulunan konsantrasyonda indoksil sülfat (PBUT) içeren simüle kanın geliştirilen mikrosistemden geçirilmesi ile indoksil sülfat adsorpsiyonunun incelendiği bu çalışmanın, klinikte $\mathrm{KBH}$ hastalarının kanında dolaşan PBUT'lerin uzaklaştırılmasını sağlayabilecek yenilikçi yöntemler geliştirilmesine yardımcı olabileceği düşünülmektedir.

\section{Teşekkür}

$\mathrm{Bu}$ çalışma "Proteine Bağlı Üremik Toksinlerin In Vitro Adsorpsiyonunun Mikroakışkan Platformda Modellemesi" başlıklı 2209/A projesi kapsamında TÜBİTAK tarafından desteklenmiştir.

\section{Kaynakça}

Armignacco P., Garzotto F., Neri M., Lorenzin A., Ronco C. (2015). Wak engineering evolution. Blood Purification, 39(1-3), 110-114.

Bergé-Lefranc, D., Vagner, C., Calaf, R., Pizzala, H., Denoyel, R., Brunet, P., ... Schäf, O. (2012). In vitro elimination of protein bound uremic toxin p-cresol by MFI-type zeolites. Microporous and Mesoporous Materials, 153, 288-293.

Caravaca, F., Arrobas, M. ve Dominguez, C. (2000). Serum Albumin and Other Serum Protein Fractions in Stable Patients on Peritoneal Dialysis. Peritoneal Dialysis International, 20, 703-707.

Davenport, A. (2014). How can dialyzer designs improve solute clearances for hemodialysis patients?. Hemodialysis International, 18(1), 43-47.

Eyüpoğlu, C. (2020). Kronik Böbrek Hastalığının Erken Tanısı için Yeni Bir Klinik Karar Destek Sistemi. Avrupa Bilim ve Teknoloji Dergisi, 20, 448-455.

Floege, J., Granolleras, C., Deschodt, G., Heck, M., Baudin, G., Branger, B., Tournier, O., Reinhard, B., Eisenbach, G.M., Smeby, L.C., et al. (1989). High-flux synthetic versus cellulosic membranes for beta 2-microglobulin removal during hemodialysis, hemodiafiltration and hemofiltration. Nephrology Dialysis Transplantation, 4(7), 653-657.

Gura, V., Rivara, M. B., Bieber, S., Munshi, R., Smith, N. C., Linke, L., et al. (2016). A wearable artificial kidney for patients with end-stage renal disease. JCI Insight, 1(8), e86397.

Ikizler, T. A., Flakoll, P.J., Parker, R.A., Hakim, R.M. (1994) Amino Acid and Albumin Losses During Hemodialysis. Kidney Internationale, 46(3), 830-837.
Kaplan, A.A., Halley, S.E., Lapkin, R.A., Graeber, C.W. (1995) Dialysate Protein Losses with Bleach Processed Polysulphone Dialyzers. Kidney Internationale, 47(2), 573578.

Krieter, D.H., Hackl, A., Rodriguez, A., Chenine, L., Moragues, H.L., Lemke, H.-D., et al. (2010). Protein-bound uraemic toxin removal in haemodialysis and post-dilution haemodiafiltration. Nephrology Dialysis Transplantation, 25(1), 212-218.

Maduell, F., Arias-Guillen, M., Fontsere, N., Ojeda, R., Rico, N., Vera, M., Elena, M., Bedini, J.L., Wieneke, P., Campistol, J.M. (2014) Elimination of Large Uremic Toxins by a Dialyzer Specifically Designed for High-Volume Convective Therapies. Blood Purification, 37(2), 125-130.

Shinzato, T., Miwa, M., Nakai, S., Takai, I., Matsumoto, Y., Morita, H., Miyata, T., Maeda, K. (1996) Alternate Repetition of Short Fore- and Back filtrations Reduces Convective Albumin Loss. Kidney Internationale, 50(2), 432-435.

Tırnakçı, B. Salt, Y., Salt, İ., Keyf, S. (2020). Klinoptilolit Dolgulu PVA Membranların Hazırlanmasi, Karakterizasyonu ve Pervaporasyon ile Desalinasyon Çalışmaları. Avrupa Bilim ve Teknoloji Dergisi, 18, 711-718.

Vanholder, R., Schepers, E., Pletinck, A., Neirynck, N. ve Glorieux, G. (2012). An Update on Protein-Bound Uremic Retention Solutes. Journal of Renal Nutrition, 22(1), 90-94.

Vanholder, R., Schepers, E., Pletinck, A., Nagler, E. V., \& Glorieux, G. (2014). The uremic toxicity of indoxyl sulfate and p-cresyl sulfate: A systematic review. Journal of American Society of Nephrology, 25(9), 1897-1907.

Yesil-Celiktas, O., Cumana, S., Smirnova, I. (2013). Silica-based monoliths for enzyme catalyzed reactions in microfluidic systems with an emphasis on glucose 6-phosphate dehydrogenase and cellulase. Chemical Engineering Journal, 234, 166-172.

Zweigart, C., Boschetti-de-Fierro, M., Neubauer, M., Storr, M., Böhler, T. ve Krause, B. (2017) Progress in the Development of Membranes for Kidney-Replacement Therapy. Comprehensive Membrane Science and Engineering (Second Edition) içinde (2. bs. Cilt 4, 214-247. ss.). Amsterdam: Elsevier B.V. 